\title{
A study of preoperative risk factors and postoperative results in patients who have undergone unilateral carotid endarterectomy
}

\section{Tek taraflı karotis endarterektomi cerrahisi yapılan hastalarda preoperatif risk faktörleri ve operasyon sonuçlarının araştırılması}

\author{
Cenk Aslan ${ }^{1}$, Fatilh Adla
}

Sancaktepe Sehit Prof Dr. Than Varank Eğitim ve Arasturma Hestanesi, Kaln ve Damar Cerrahisi Kliniŏi, Istanbul, Turkey

${ }^{2}$ Cumhuriyet University Scho ol of Medicine, Cardiovascular Surgery Department, Sivas, Turkey

Corresponding author: Fatih Ada,Assitant Proffesor, Cumhuriyet University School of Medicine, Cardiovascular Surgery Department, Sivas,

Turkey

E-mail: drfatihada@gmail.com

Received/Accepted: June 13, 2018 / December 26, 2018

Conflict of interest: There is not a conflict of interest.

\section{SUMMARY}

Objective: In this study, the relationship between preoperative risk factors and operative outcomes in patients undergoing unilateral carotid endarterectomy was compared in the light of literature reviews.

Method: 223 patients who underwent unilateral carotid endarterectomy in Dr.Siyami Ersek Breast Heart and Vascular Surgery Training and Research Hospital in the years between 2007 and 2009 were included in the study. The mean age of the patients was $68.13 \pm 5,25$ and $29,5 \%$ of them were women $(n=66)$ while $70,5 \%$ of them were men $(n=157)$. $43.5 \%$ of patients $(n=97)$ had hypertension and $61.2 \%$ of patients $(n=136)$ had diabetes mellitus. $76.1 \%$ of patients $(n=$ $170)$ had a history of smoking while $29.3 \%$ of patients $(n=65)$ had hyperlipidemia. In $5.4 \%(n=12)$ of patients experienced perioperative stroke, $10.8 \%(\mathrm{n}=24)$ of patients had a history of prolonged neurologic disease and $6.8 \%(\mathrm{n}$ $=15$ ) of patients had experienced transient ischemic attacks.

Results: Patients undergoing carotid endarterectomy in the postoperative period were followed under 3 main headings: early neurologic complications, early cardiac arrhythmias and other complications (multiple organ failure, respiratory problems and hypertension). Early neurologic complications in patients were followed by the frequency of stroke, transient ischemic attack (TIA), and prolonged reversible ischemic neurological disease (PRIND). In this group, the rate of stroke patients in the postoperative period was $2.2 \%(n=5)$ while the rate of TIA or PRIND patients was $4.1 \%(n=$ 9).

Conclusions: Reducing mortality and morbidity after carotid artery endarterectomy is possible with a good analysis of preoperative risks and a good preoperative preparation. Cardiovascular surgeons have a great role and responsibility to reduce the risk and complications of carotid artery endarterectomy in preoperative, intraoperative and postoperative periods.

Keywords: Carotid artery diseases; carotid stenosis; neurological symptom; surgical treatment

Amaç: Bu çalışmada, tek taraflı karotis endarterektomi operasyonu yapılan hastalarda preoperatif risk faktörleri ile operasyon sonuçları arasındaki ilişki literatür sonuçları eşliğinde karşılaştırıldı.

Yöntem: Çalışmaya İstanbul Dr. Siyami Ersek Göğüs Kalp ve Damar Cerrahisi Eğitim ve Araştırma Hastanesinde 20072009 yılları arasında tek taraflı karotis endarterektomi operasyonu yapılan 223 hasta dâhil edildi. Hastaların yaş ortalamas1 $68.13 \pm 5,25$ ve $\% 29,5^{\prime}$ i $(n=66)$ kadın, \%70,5'i (n=157) erkek idi. Hastaların \%43,5'ünde (n=97) hipertansiyon, \%61,2'sinde ( $\mathrm{n}=136)$ ise diabetes mellitus mevcuttu. Sigara kullanımı hikâyesi \%76,1 (n=170) hastada mevcut iken, hastaların \%29,3'sinde $(\mathrm{n}=65)$ hiperlipidemi mevcut idi. Hastaların \%5,4'ünde $(\mathrm{n}=12)$ operasyon 
öncesinde geçirilmiş stroke öyküsü bulunurken, \%10,8'inde (n=24) uzamış nörolojik defisit hikâyesi ve \%6,8'inde $(\mathrm{n}=15)$ geçirilmiş geçici iskemik atak bulunmaktaydi.

Bulgular: Postoperatif dönemde karotis endarterektomi yapılan hastalar 3 ana başlık altında takip edildi. Bunlar; erken nörolojik komplikasyonlar, erken kardiyak aritmiler ve diğer komplikasyonlardır ( multiple organ yetmezliği, respiratuar problemler ve hipertansiyon). Erken nörolojik komplikasyonlar yönünden hastalar stroke geçirme, geçici iskemik atak (TIA) ve uzamış reversible iskemik hastalık (URID) atağı geçirme sıklığı takip edildi. Bu grupta postoperatif dönemde stroke geçiren hastaların oranı $\% 2,2(\mathrm{n}=5)$ iken, TIA ya da URID geçiren hastaların oranı $\% 4,1$ $(\mathrm{n}=9)$ olarak bulundu.

Sonuç: Karotis arter endarterektomi sonrası mortalite ve morbiditenin azaltılması preoperatif risklerin iyi bir şekilde analiz edilmesi ve iyi bir preoperatif hazırlık evresi ile mümkündür. Karotis arter endarterektomi cerrahisindeki risklerin ve komplikasyonların azaltılmasında ise preoperatif, intraoperatif ve postoperatif olarak kardiyovasküler cerrahlara büyük bir görev ve sorumluluk düşmektedir.

Anahtar sözcükler: Karotis arter hastalıkları, karotis darlığı, nörolojik semptom, stroke, cerrahi tedavi

\section{INTRODUCTION}

Carotid artery disease is one of the most important causes of stroke etiology, and atherosclerosis is responsible for about one-third of all induced strokes ${ }^{1}$. Carotid artery disease does not only cause a wide variety of neurological events ranging from transient ischemic attack to far advanced neurological deficits but it may also result in death. These consequences lead to the deterioration of the patient's quality of life; they cause familial, social and psychosocial problems and they also become an additional financial burden on health insurance. The disease has some known risk factors that are preventable such as smoking cessation, hypertension control, and blood lipid level control. When the disease develops, various revascularization methods are applied in the treatment. There is a broad range of variety in these methods ranging from interventional procedures such as stenting to standard carotid artery endarterectomy. Many studies have shown that revascularization reduces the incidence of stroke and mortality in patients with carotid artery stenosis, whether symptomatic or asymptomatic. In the treatment of revascularization; there are many studies showing the advantages or disadvantages of interventional therapies and traditional surgical treatment. However, it is far too early to reach a definite conviction. In our study; the relationship between preoperative risk factors and operation outcomes in patients undergoing unilateral carotid endarterectomy was compared in the light of literature results.

\section{MATERIAL AND METHODS}

The aim of the study is to reveal the relationship between preoperative risk factors and operative outcomes in patients who underwent unilateral carotid endarterectomy in Dr.Siyami Ersek Breast Heart and Vascular Surgery Training and
Research Hospital in the years between 2007 and 2009.

223 patients who underwent unilateral carotid endarterectomy in our hospital in the years between 2007 and 2009 were included in the study. Patient information was obtained from the registration system in our hospital. The study was approved by the ethical committee of Dr.Siyami Ersek Breast Heart and Vascular Surgery Training and Research Hospital. Written consent was obtained from the patients included in the study. Three patients who had undergone carotid artery endarterectomy between 2007 and 2009 died from various causes during the early postoperative period.

Patients were evaluated for age, sex, weight, height, hypertension, diabetes mellitus, smoking habits, hyperlipidemia, preoperative symptom, coronary artery disease, peripheral arterial disease, family history of cardiovascular disease, stroke, prolonged neurologic disease and transient ischemic attack.

Patients with carotid lesions were classified as asymptomatic and symptomatic. Patients who were symptomatic were those with focal or transient neurological symptoms, and patients with amorozis fugax or previous stroke. In asymptomatic patients, there were no neurological findings or a history of neurological disorders.

The following methods were used to establish surgical indications for our patients: In symptomatic cases, indications for surgical treatment were kept wide. Surgical indications were established for patients with stenosis of up to $50 \%$, patients with large ulcerative and soft plaques, patients with a stenosis above $70 \%$ in asymptomatic cases, bilateral carotid stenosis and symptomatic patients, even if the stenosis was below $70 \%$, moreover if the contralateral stenosis 
was above $70 \%$, the opposite side was also indicated for surgery.

\section{Surgical Technique-Intensive Care- Discharge}

All patients underwent classic carotid endarterectomy. Under general anaesthesia, common, internal and external carotid arteries were found, passing through skin-subcutaneous tissue with a longitudinal incision from the medial head anterior to the sternocleidomastoid muscle along the line extending from the earlobe to the sternoclavicular junction and the silastik tape was wrapped. Following heparinization with a loading dose of $5000 \mathrm{U}$, vascular clamps were placed and incisions were made up to the intact segment of the internal carotid artery from the common carotid artery. Endarterectomy was performed from the common carotid artery to the intact segment of the internal carotid artery. The endarterectomy material was removed from the external carotid artery to the healthy segment. Taking into account the carotid state, arteriotomy was performed with 6.0 polypropylene sutures using primer closure, autogenous vein or synthetic grafts. All of the patients were admitted in intensive care units and patients were extubated once they met the criteria for extubation. Neurological examinations were closely followed in patients' postoperative intensive care units. Patient antihypertensive treatment required for blood pressure regulation was given as intravenous infusion. The patients in need received antihypertensive treatment as an intravenous infusion for blood pressure regulation. Patients were placed on a follow up plan at convenient times considering their general conditions.

\section{Statistical Analysis}

In the study, continuous variables were expressed as mean \pm SD and categorical variables as frequency and percentage. SPSS 24 package statistical program (StataCorp LP, College Station, TX, USA) was used for all descriptive statistics and calculations.

\section{RESULTS}

The average age of the patients included in the study was $68.13 \pm 5,25$ and $29,5 \%$ of them were women $(n=66)$ while $70,5 \%$ of them were men $(n=157) . \quad 43.5 \%$ of patients $(n=97)$ had hypertension and $61.2 \%$ of patients $(n=136)$ had diabetes mellitus. $76.1 \%$ of patients $(n=170)$ had a history of smoking while $29.3 \%$ of patients $(n=$ 65) had hyperlipidemia (Table 1). In 5.4\% ( $\mathrm{n}=$ 12) of patients experienced perioperative stroke, $10.8 \%(n=24)$ of patients had a history of prolonged neurologic disease and $6.8 \%(n=15)$ of patients had experienced transient ischemic attacks (Table 2).

Table 1: Preoperative and demographic data of the patients

\begin{tabular}{|ll|}
\hline \multicolumn{2}{|l|}{ Demographic data of patients undergoing carotid endarterectomy $(\mathbf{n = 2 2 3})$} \\
\hline Age (Years) & $68.13 \pm 5,25$ \\
Female sex (n=66) (\%) & 29,5 \\
Male sex (n=157) (\%) & 70,5 \\
Height (Meter) & $1.67 \pm 6,31$ \\
Weight (Kilogram) & $79.76 \pm 9,4$ \\
Hypertension (n=97) (\%) & 43,5 \\
Diabetes mellitus (n=136) (\%) & 61,2 \\
Tobacco use (n=170) (\%) & 76,1 \\
Hyperlipidemia (n=65) (\%) & 29,3 \\
Statin use (n=167) (\%) & 75,2 \\
Preoperative symptom (n=174) (\%) & 78,2 \\
\hline
\end{tabular}




\begin{tabular}{|ll|}
\hline Coronary artery disease $(\mathrm{n}=72)(\%)$ & 32,3 \\
Peripheral artery disease $(\mathrm{n}=34)(\%)$ & 15,4 \\
Family History $(\mathrm{n}=12)(\%)$ & 5,2 \\
Previous aortocoronary bypass graft operation $(\mathrm{n}=40)(\%)$ & 18,2 \\
Stroke $(\mathrm{n}=12)(\%)$ & 5,4 \\
Prolonged neurologic disease $(\mathrm{n}=24)(\%)$ & 10,8 \\
Transient ischemic attack $(\mathrm{n}=15)(\%)$ & 6,8 \\
\hline
\end{tabular}

Table 2: Types of symptoms according to region

\begin{tabular}{|l|}
\hline Dispersiyon rates of symptoms $(\mathbf{n}=\mathbf{2 2 3})$ \\
\hline Bilateral asymptomatic $(\mathrm{n}=65)$
\end{tabular}

The coronary artery disease rate was $32.3 \%(\mathrm{n}=$ $72)$ and $18.2 \%(n=40)$ of the patients had coronary artery bypass surgery history. Concomitant peripheral artery disease rate was found to be $15.4 \%(n=34)$. According to the region where the carotid endarterectomy surgery is made; the right side was found in $53.2 \%$ $(\mathrm{n}=118)$ and the left side was found in $46.8 \%$ $(\mathrm{n}=105)($ Graph 1).

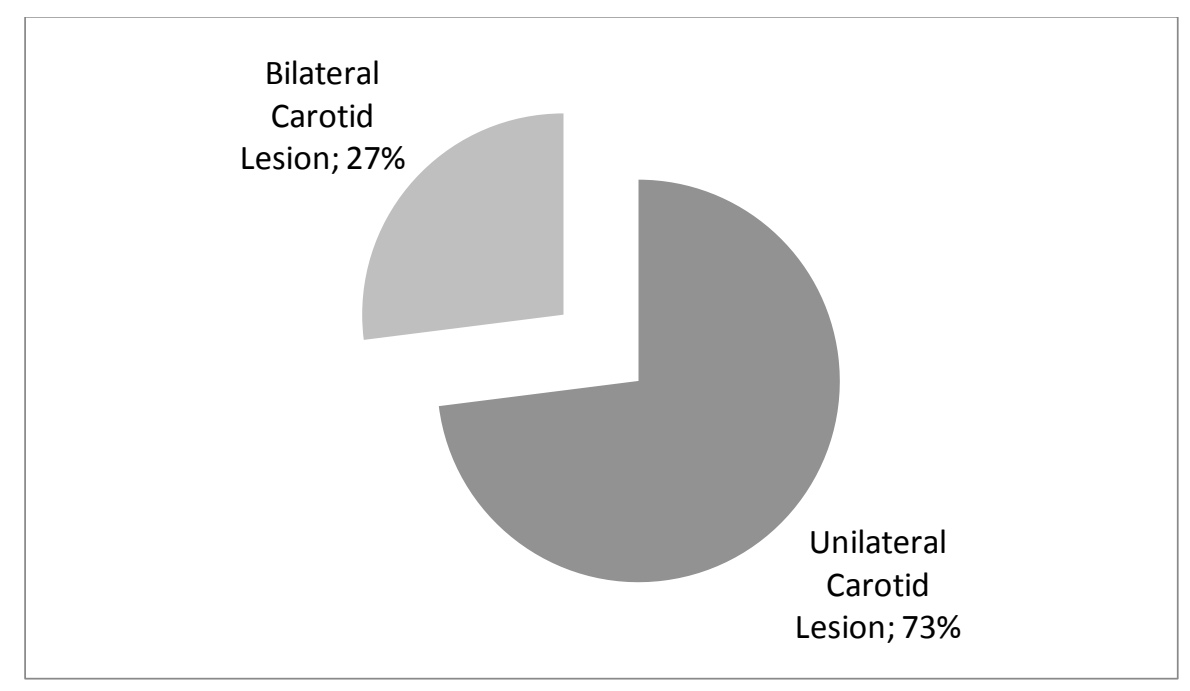

Graphic 1: Dispersion of unilateral - bilateral carotid lesions $(n=223)$ 
Patients undergoing carotid endarterectomy in the postoperative period were followed under 3 main headings: early neurologic complications, early cardiac arrhythmias and other complications (multiple organ failure, respiratory problems and hypertension). Early neurologic complications in patients were followed by the frequency of stroke, transient ischemic attack, and prolonged reversible ischemic neurological disease. In this group, the rate of stroke patients in the postoperative period was $2.2 \%(\mathrm{n}=5)$ while the rate of TIA or PRIND patients was $4.1 \%(\mathrm{n}=9)$.
In terms of early cardiac problems, $1.1 \%(\mathrm{n}=2)$ of patients followed for myocardial infarct, ventricular arrhythmia and low flow syndrome had myocardial infarct after carotid endarterectomy. Ventricular arrhythmia was seen in $2.7 \%(n=6)$ of patients and low flow syndrome was detected in $1.3 \%(\mathrm{n}=3)$. Multiple organ failure occurred in $0.8 \%$ of the patients $(\mathrm{n}=1)$ postoperatively, Respiratory problems were found in $5,4 \%(\mathrm{n}=12)$ and hypertension in $9,3 \%(\mathrm{n}=$ 20) of the patients (Table 3 ).

Table3: Postoperative complications (TIA: Transient ischemic attack; PRIND: prolonged reversible ischemic neurological disease)

\begin{tabular}{|ll|}
\hline Postoperative complications & \\
\hline Early neurological complications & $\% 2,2$ \\
$\quad$ Stroke (n=5) & $\% 4,1$ \\
TIA or PRIND (n=9) & \\
& \\
Early cardiac complications & $\% 1,1$ \\
Myocardial infarction ( $\mathrm{n}=2)$ & $\% 2,7$ \\
Ventricular arrhythmias ( $\mathrm{n}=6)$ & $\% 1,3$ \\
Low cardiac output syndrome (n=3) & \\
& \\
Other Complications & $\% 0,8$ \\
Multiple organ failure (n=1) & $\% 5,4$ \\
Respiratory complications (n=12) & \\
Hypertension (n=20) & \\
&
\end{tabular}

Between 2007 and 2009, the early mortality rate of 223 carotid endarterectomy cases in Dr.Siyami Ersek Thoracic and Cardiovascular Surgery
Training and Research Hospital was found as $1.3 \%(n=3)$ (Table 4). 
Table 4: Carotid endarterectomy early mortality rate

\begin{tabular}{|l|l|}
\hline Carotid endarterectomy mortality rate \\
\hline Early mortality $(\mathrm{n}=3)$ & $\% 1,3$ \\
\hline
\end{tabular}

\section{DISCUSSION}

Carotid artery disease is among the leading causes of death and it is still a challenge to find the ideal treatment of this disease, which causes such serious consequences in addition to death as money and labor loss and obligates the patient to refrain from social and business life. The inadequacy of medical treatment to prevent this disease or at least the necessity of supporting medical treatment by other treatment methods is known.

In the studies conducted, the necessity of carotid endarterectomy in symptomatic patients has become definite ${ }^{5-7}$. "North American Symptomatic Carotid Endarterectomy Trial" (NASCET), one of these studies, is considered as a milestone in the history of carotid surgery and is a supportive point for surgical treatment. The NASCET is a major study series not only for the result it reaches, but also for its decisive influence on subsequent studies; it even has an effect on the formation of endovascular treatment criteria. However, the issue that is particularly concerned about, especially with endovascular treatment, is the patient population on which the NASCET study is based. The NASCET is a study which excludes the patients who have difficult-to-reach lesion on the $\mathrm{C} 2$ vertebrae, who have a total carotid occlusion, who are older than 79 and have no symptom on the side of the stenotic lesion on the side of the hemisphere, who have organ failure, who are expected to die from cancer in 5 years, who have a massive cerebral infarct that would affect all the functions of the patient in that area, who experience symptoms related to nonatherosclerotic causes, who have cardioembolic cerebral vascular disease which occurred as a result of valve disease or arrhythmia, who have not experienced ischemic stroke events with relevant ischemic lesions in the last 120 days, and who had previously undergone ipsilateral endarterectomy.
The same conclusions were reached in the study of " European Carotid Surgery Trial " (ECST). Neurological findings were $8.6 \%$ in the carotid endarterectomy group and $13.6 \%$ in the medical treatment group during the 2.7-year follow-up period $^{9-13}$.

In a single-center study with 2624 patients made by Cremonesi and his friends, Carotid endarterectomy was performed in 1589 patients and carotid endovascular stenting was performed in 1035 patients using a distal embolic protection device. In the study, the 30th day, the 1st year and the 3rd year stroke and mortality rates were respectively as follows: in the group who underwent carotid endovascular stent the rates were $1.54 \%, 2.86 \%, 7.43 \%$ and in the carotid endarterectomy group the rates were $2.07 \%$, $3.55 \%$ and $6.95 \%{ }^{14}$. In 2004, the "Stenting and Angioplasty with Protection in Patient at High Risk for Endarterectomy" (SAPPHIRE) study group published 1 year results of carotid artery stenting performed with distal protection filter on 334 patients, including 80-year-olds and cases with high-risk of surgery. According to this, the 30-day death, stroke or MI rate was reported as $4.4 \%$ and 1 year rates as $12 \%$. The 30 -day death, stroke or myocardial infarct rate was $9.9 \%$ and the annual rate was $20.1 \%$ in the same study group with carotid endarterectomy cases ${ }^{15}$.

"Veterans Affairs Cooperative Study" is the first conclusive multicenter study which involved asymptomatic patients. This study has proved that carotid endarterectomy is also necessary in asymptomatic patients. Because neurological findings were observed as $20.6 \%$ in the group which received only medical treatment while these findings were $8 \%$ in the group which underwent carotid endarterectomy and received postoperative antiplatelet treatment ${ }^{16}$.

Apart from the Veterans Affairs Cooperative Study Group study, there are some reasons which make surgical intervention necessary for 
asymptomatic patients. These reasons are as follows: Carotid artery stenoses evolve into full obstruction in a shorter period than expected, approximately half of the cerebral infarcts associated with stenosis in the carotid develop without TIA, 10-15\% cerebral infarcts do not show clinical signs, prior TIAs should be considered pathologic because infarct areas are detected by computerized tomography in 30-40\% of these patients. Mortality and morbidity of surgery in symptomatic patients is greater than asymptomatic patients. Therefore, the time spent waiting may lead to the formation of symptomatic nature of the disease and thus increase the mortality and morbidity ${ }^{16}$.

Considering the views referred above, when our study is examined, it is obvious that there are many factors affecting operative mortality and morbidity negatively in the patient group such as diabetes mellitus, hypertension, hyperlipidemia, coronary artery disease and past cardiac operation as well as the age of the patients. Despite all these negative risk factors, the perioperative mortality of 223 carotid endarterectomy cases in our hospital was found to be $1.3 \%$ and the transient neurological finding were $6.3 \%$.

These results are less than the perioperative complication rates reported by the American Heart Association ${ }^{17}$.

\section{CONCLUSION}

Reducing mortality and morbidity after carotid artery endarterectomy is possible with a good analysis of preoperative risks and a good preoperative preparation. Cardiovascular surgeons have a great role and responsibility to reduce the risk and complications of carotid artery endarterectomy in preoperative, intraoperative and postoperative periods.

\section{REFERENCES}

1. Liapis CD, Bell PR, Mikhailidis D, Sivenius J, Nicolaides A, Fernandes e Fernandes J, et al. ESVS guidelines. Invasive treatment for carotid stenosis: indications, techniques. Eur J Vasc Endovasc Surg 2009;37(4 Suppl):1-19.

2. Hıdıroğlu M, Çetin L, Kunt A, Karakişi O, Küçüker A, Şener E. Karotis arter hastalıklarında karotis endarterktomi erken sonuçları. Turk Gogus Kalp Dama 2010;18:190-5.

3. Beneficial effect of carotid endarterectomy in symptomatic patients with high-grade carotid stenosis. North American Symptomatic Carotid Endarterectomy Trial Collaborators. N Engl J Med 1991;325:445-53.
4. Hobson RW 2nd, Mackey WC, Ascher E, Murad MH, Calligaro KD, Comerota AJ, et al. Management of atherosclerotic carotid artery disease: clinical practice guidelines of the Society for Vascular Surgery. J Vasc Surg 2008;48:480-6

5. Callow AD. Recurrent stenosis after carotid endarterectomy. Arch Surg 1982;117:1082-1085

6. Mattos MA, Hodgson KJ, Londrey GL, et al. Carotid endarterectomy: operative risks, recurrent stenosis, and long term stroke rates in a modern series. JCarovasc Surg 1992;33:387-400

7. Civil ID, O’Hara PJ, Hertzer NR, Krajewski LP, Beven EG. Late patency of thecarotid artery after endarterectomy. Problems of definition, follow-up methodology, and data analysis. J Vasc Surg 1988; 8: 79-85.

8.NASCET Investigators. North American Symptomatic Carotid Endarterectomy Trial: methods, patient characteristics, and progress. Stroke 1991;22:711-720

9. Beard JD. Does serial postoperative clinical or duplex surveillance reduce long- term stroke risk In: Naylor AR, Mackey WC, eds. Carotid Artery Surgery: AProblem- based Approach. London, UK: Harcourt Publishers Ltd, 2000: 360-6

10. Beard JD. Does serial postoperative clinical or duplex surveillance reduce the long-term stroke risk? In: Naylor AR, Mackey WC, eds. Carotid Artery Surgery: A Problem-based Approach. London, UK: Harcourt Publishers Ltd, 2000: 3606.

11. BARI investigators. Seven-year outcome in the by-pass angioplasty revascularization investigation (BARI) by treatment and diabetic status. J Am CollCardiol 2000; 35:112-119.

12. Cho JS, Pandurangi K, Conrad MF et al. Safety and durability of redo carotid operation: an 11-year experience. J Vasc Surg2004; 39: 155-61.

13. European Carotid Surgery Trialists' Collaborative Group. MRC European Carotid Surgery Trial: interim results for symptomatic patients with severe $\mathbf{( 7 0 - 9 9 \% )}$ or with mild (029\%) carotid stenosis. Lancet. 1991 May 25;337:1235-43.

14. Cremonesi A, Manetti R, Setacci F, Setacci C, Castriota F. Protected carotid stenting: clinical advantages and complications of embolic protection devices in 442 consecutive patients, Stroke , 2003, vol. 34 (pg. 1936-1941) 
15. Massop, D. , Dave, R. , Metzger, C. , Bachinsky, W. , Solis, M., Shah, R. , Schultz, G. , Schreiber, T., Ashchi, M. and Hibbard, R. (2009), Stenting and Angioplasty with Protection in Patients at High-Risk for Endarterectomy: SAPPHIRE Worldwide Registry First 2,001 Patients. Cathet. Cardiovasc. Intervent., 73: 129136.

16. Mayberg MR, Wilson SE, Yatsu F, Weiss DG, Messina L, Hershey LA, Colling C, Eskridge J, Deykin D, Winn HR; Veterans Affairs Cooperative Studies Program 309 Trialist Group. Carotid endarterectomy and prevention of cerebral ischemia in symptomatic carotid stenosis. JAMA.

1991;266:3289-3294

17. Mosca L, Benjamin EJ, Berra K, Bezanson JL, Dolor RJ, Lloyd-Jones DM, Newby LK, Pina IL, Roger VL, Shaw LJ, Zhao D, Beckie TM, Bushnell C, D'Armiento J, Kris-Etherton PM, Fang J, Ganiats TG, Gomes AS, Gracia CR, Haan CK, Jackson EA, Judelson DR, Kelepouris E, Lavie CJ, Moore A, Nussmeier NA, Ofili E, Oparil S, Ouyang P, Pinn VW, Sherif K, Smith SCJr., Sopko G, ChandraStrobos N, Urbina EM, Vaccarino V, Wenger NK. Effectiveness-based guidelines for the prevention of cardiovascular disease in women: 2011 update: a guideline from the American Heart Association, J Am Coll Cardiol , 2011, vol. 57 (pg. 1404-1423) 